\title{
Editorial
}

\section{Recent Advances in Solar Cells}

\author{
Armin Aberle \\ ARC Photovoltaics Centre of Excellence, School of Photovoltaic and Renewable Energy Engineering, \\ The University of New South Wales, Sydney, NSW 2052, Australia
}

Received 23 December 2007; Accepted 23 December 2007

Copyright (c) 2007 Armin Aberle. This is an open access article distributed under the Creative Commons Attribution License, which permits unrestricted use, distribution, and reproduction in any medium, provided the original work is properly cited.

The photovoltaics (PV) industry is booming, with annual growth rates well in excess of $30 \%$ per year over the last decade. This explosive growth has been driven by rapidly increasing fossil fuel prices, an almost universal acceptance of the link between global warming and human activity, the growing realisation of a gap between the increasing global demand for energy and the ability to supply, the implementation of market development programs to accelerate the deployment of sustainable energy options (particularly in Germany and Japan, but more recently also in Spain, France, Italy, South Korea, and several US states), and the escalating interest of the financial investment community in the business opportunities created by this rapid expansion. Sector revenue was over $€ 15$ billion in 2007 and is expected to exceed $€ 100$ billion/year within less than 10 years. Many studies have identified PV as the most promising of presently known energy generation options for a globally sustainable energy future, and many experts are convinced that PV-due to its unique advantages - will conquer a significant share of the global power market in the coming decades.

While current PV module production is around $3 \mathrm{GW}_{\mathrm{p}}$ (gigawatt peak) per year, production levels of hundreds of gigawatts per year are required to contribute measurably to global electricity generation. The main challenge along this path is ongoing incremental reductions of the cost of PV-generated electricity $(€ / \mathrm{kWh})$. This requires continuous reductions of the manufacturing cost per unit area of the PV modules $\left(€ / \mathrm{m}^{2}\right)$, continuous improvements of the energy conversion efficiency of the modules (i.e., an improved $\mathrm{W}_{\mathrm{p}} / \mathrm{m}^{2}$ figure), or a combination of both, giving lower $€ / \mathrm{W}_{\mathrm{p}}$ costs for the modules.

Today's mainstream PV technology (market share of about $90 \%$ ) is based on crystalline silicon wafers. As outlined in this special issue, despite their maturity, silicon wafer-based PV technologies still have enormous potential with respect to lowering the $€ / \mathrm{W}_{\mathrm{p}}$ costs of PV modules.
While today's silicon wafer-based modules cost $€ 2-3$ per $W_{p}$ to fabricate, it is realistic to assume that in 10 years, they will be fabricated at costs of $€ 1.2-1.5$ per $\mathrm{W}_{\mathrm{p}}$. Thus, given the high conversion efficiency of silicon wafer-based modules, their proven long-term stability in the field ( $>20$ years), and the robustness of the solar cell fabrication process, this PV technology is likely to dominate the PV market for at least another decade.

Due to greatly reduced semiconductor material consumption and the ability to (i) fabricate the solar cells on inexpensive large-area foreign substrates and (ii) to monolithically series-connect the fabricated solar cells, thin-film photovoltaics has the potential of achieving module fabrication costs of well below $€ 1$ per $W_{p}$. As described in this special issue, thin-film PV technologies are developing rapidly, both in the laboratory and in industry. While amorphous silicon-based PV modules have been around for more than 20 years, recent industrial developments include the first polycrystalline silicon thin-film solar cells on glass and the first tandem solar cells based on stacks of amorphous and microcrystalline silicon films (micromorph cells). Globally, more than a dozen thin-film silicon PV lines are presently being commissioned or planned for amorphous and/or micromorph solar cells. The coming years will show whether these new thin-film silicon PV factories can compete with the established silicon wafer-based PV technologies. Significant thin-film PV production levels are presently also being set up for CIS (copper indium diselenide) and CdTe (cadmium telluride). The latter technology is expanding particularly rapidly, primarily due to First Solar. This company alone now has a global production capacity of about $200 \mathrm{MW}_{\mathrm{p}} /$ year for thin-film PV modules.

Another area that is developing very well is the highestperformance concentrator solar cells based on epitaxial gallium arsenide films and their relatives. The article by Richard King's team at Spectrolab reports on the world's first $40 \%$ 
efficient solar cells. This landmark result was achieved for a commercially relevant light concentration level ( 200 suns) and a small number of solar cells in the stack (three). These very high cell efficiencies give hope that concentrator PV systems will soon be commercially competitive in many cloudfree regions of the world.

As can be concluded from the articles on dye-sensitised solar cells, this technology is also promising and has the potential to be commercially relevant for standard 1-sun applications within a decade. Furthermore, this special issue contains an article on "futuristic" solar cells based on silicon quantum dots. Artificial semiconductor materials featuring nanostructures might be necessary to realise the ultimate dream of ultra-high PV efficiency at low cost.

Armin Aberle 

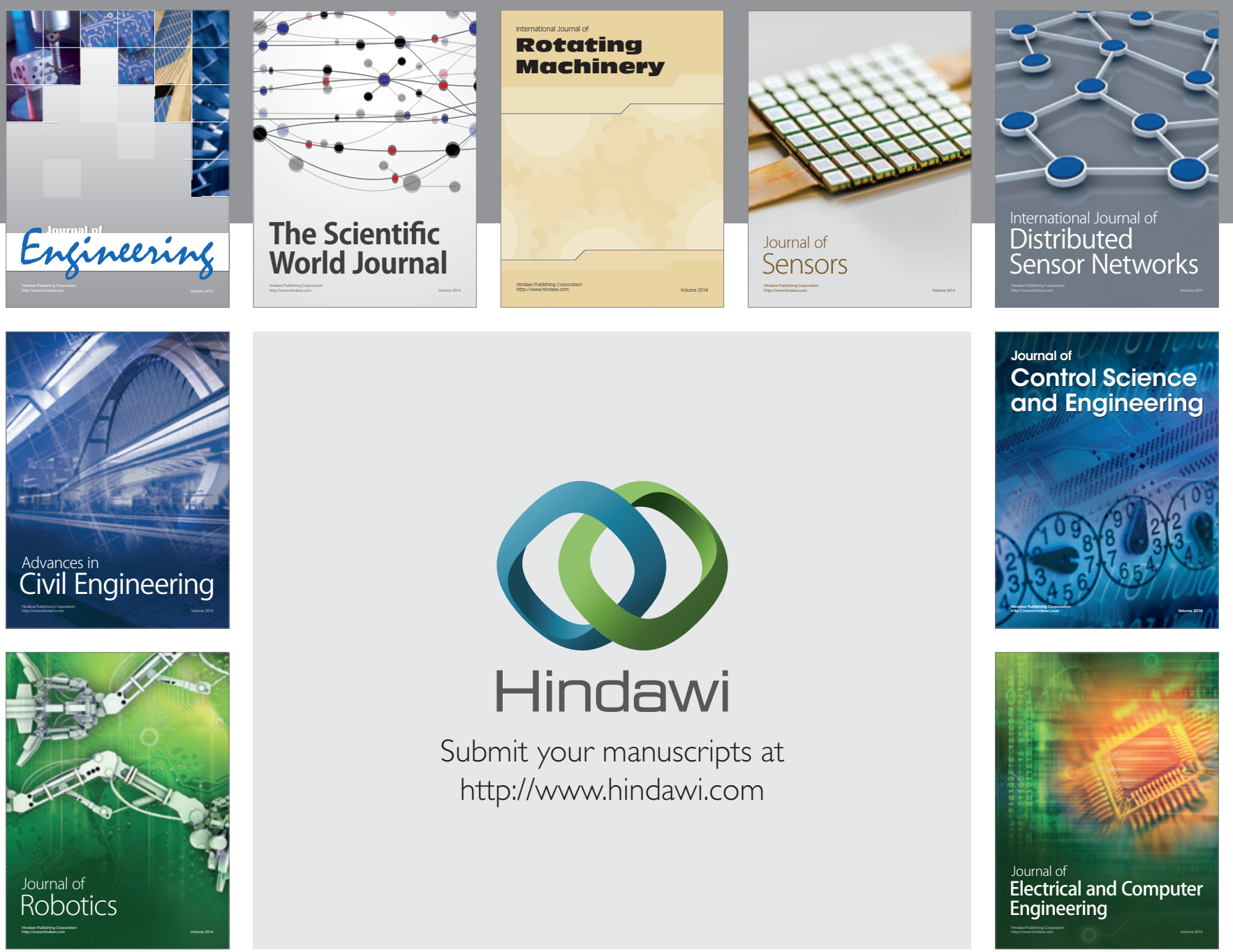

Submit your manuscripts at

http://www.hindawi.com
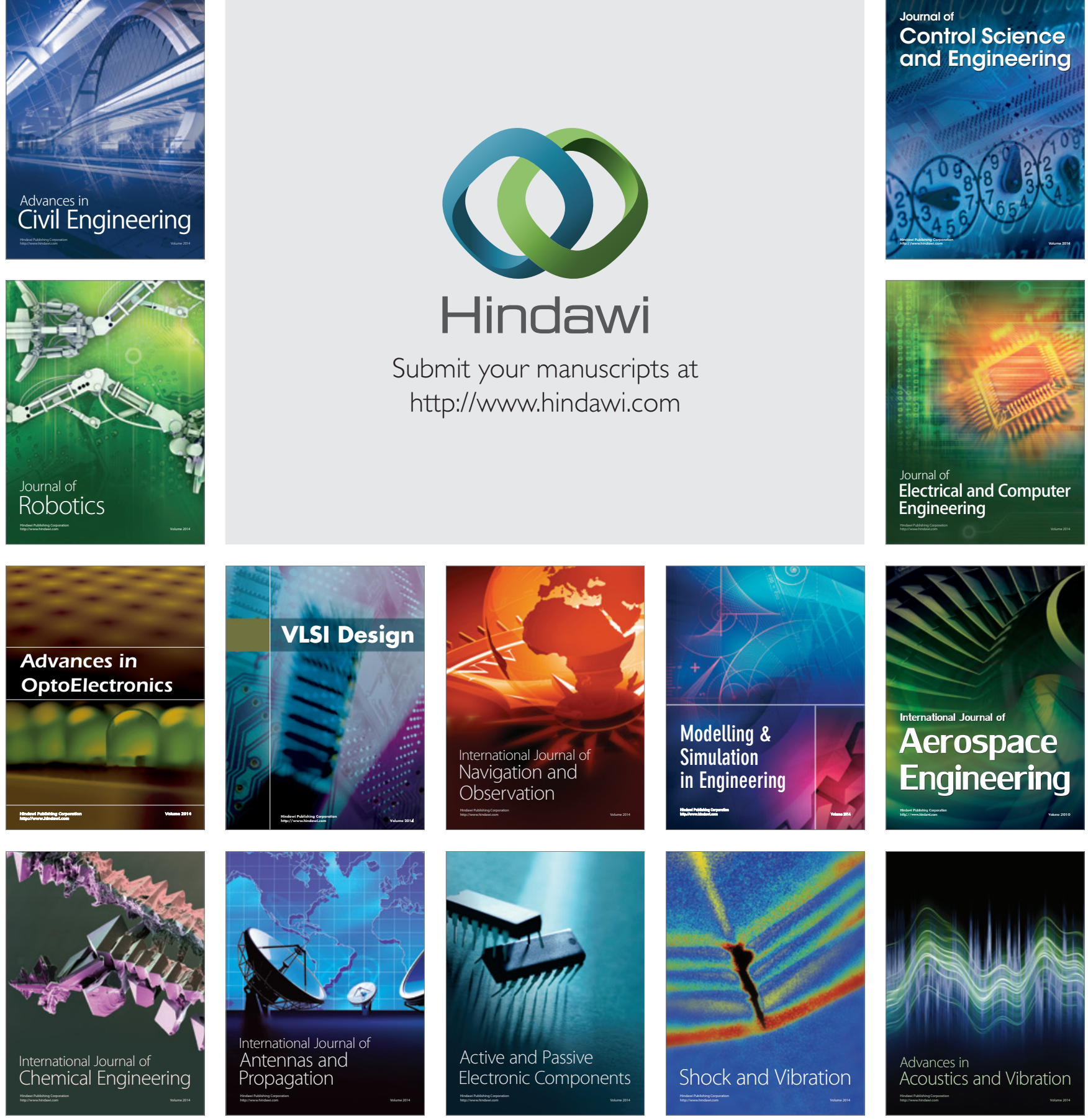